8. Anderson, R. (1959). Japan: three epochs of modern education. Washington. Bulletin U.S. Department of Health, education and Welfare. № 11. Retrieved from: https://files.eric.ed.gov/fulltext/ ED045543.pdf (in Eng.).

9. Tokutake, T. (1995). The Postwar History of Japanese. Tokyo. (in Eng.).

10. Kinichi, T. (1997). Kokumin Gakkp: Kфkoku no Michi. Tokyo. (in Eng.).

11. Yamanaka, H. (1989). Bokura Shфkokumin. Tokyo. (in Eng.).

TROFYMCHENKO Anastasia, Graduate student of the Department of World History, Borys Grinchenko Kyiv University, e-mail: at@academy.com.ua

\title{
PECULIARITIES OF IMPLEMENTATION OF EDUCATIONAL REFORMS IN JAPAN AFTER THE SECOND WORLD WAR
}

\begin{abstract}
Introduction. The article considers the stages of educational reforms implementation in the postwar period and their impact on schooling. Special attention is paid to the study of educational ideas in the pre-war and post-war period. The activities of the Japanese government and the occupation regime to eliminate illiteracy among various segments of the population are considered. A special role is given to the issue of military influence withdrawal from school education. The processes of introduction of "progressive education" by the US occupation regime, which played a key role in the reform process, have been updated.
\end{abstract}

Purpose. The aim of the proposed article is to study the educational reforms in the postwar period in Japan.

Results. Summarizing the research of historians, we can draw our own analytical conclusions about the development of the educational system in Japan. The processes of implementation of school reforms in the postwar period are studied. The role and influence of the occupation regime, its introduction of changes in schooling are determined.

Conclusion. Changes in Japan's education policy in the postwar period have yielded positive results, as evidenced by the increase in the number of educational institutions in the country. During the occupation period, the basis of the established regime was the introduction of democratization and demilitarization of the country. Education was one component of such a plan. The introduction of reforms in education has made it possible to achieve changes in the ideological views of the younger generation. The key role in the new educational concepts was played by the US missions in Japan, which operated there during the 1946-1950s. The reform of the Japanese educational system became a kind of springboard for further progressive changes in the country.

Key words: education, reforms, school, Japan, government, occupation, militarism, World War II. Одержано редакцією 17.03.2021

Прийнято до публікації 29.06.2021

УДК 711.4:719(575.3)

DOI: 10.31651/2076-5908-2021-1-118-125

\section{ХАРКОВЕНКО Роман Володимирович,} кандидат історичних наук, головний спеціаліст Міністерства культури та інформаційної політики України, Orcid ID: 0000-0002-3447-1391 e-mail: kredo3@ukr.net

\section{МІСТОБУДІВНЕ РЕГУЛЮВАННЯ У СФЕРІ ОХОРОНИ КУЛЬТУРНОЇ СПАДЩИНИ РЕСПУБЛІКИ ТАДЖИКИСТАН}

У статті аналізується питання містобудівного регулювання у сфері охорони культурної спадщини Республіки Таджикистан. Здійснено огляд пам'яткоохоронного законодавства $i$ принципів державного управління, а також досліджено роль культурної спадщиини у житті 
народу вказаної республіки. Виокремлено національні особливості виявлення, дослідження, обліку, охорони, збереження й використання пам'яток культурної спадщини у Республіці Таджикистан.

Ключові слова: культурна спадщина, охорона культурної спадщини, об'єкт культурної спадщини, пам'ятка, містобудівна діяльність.

Постановка проблеми. Кожна країна у світі прагне якомога ефективніше охороняти i зберігати свою національну культурну спадщину. У законодавствах переважної більшості держав світу пам'ятки культурної спадщини поділяються на три категорії: місцевого, національного та міжнародного (всесвітнього, світового) значення (пам'ятки ЮНЕСКО). Останні за відповідним рішенням вказаної міжнародної організації заносяться до Списку Всесвітньої спадщини ЮНЕСКО.

Скільки держав у світі, стільки ж і практик існує щодо охорони власної культурної спадщини, іiі збереження, використання та популяризації. Крім того, надзвичайно важливим $\epsilon$ аспект містобудівного регулювання у сфері охорони культурної спадщини, оскільки міста постійно будуються, змінюються, й розвиваються. Отже, потрібно виважено і розумно вибудувати державну політику з означеного питання, щоб створити умови для збереження та охорони пам'яток культурної спадщини, а також забезпечити будівництво нових споруд. Акцент необхідно зробити на гармонійному існуванні і пам'яток, і новобудов. На нашу думку, дуже цікавим є момент поєднання збереження власної багатої культурної спадщини з розвитком міст Республіки Таджикистан.

Аналіз останніх досліджень і публікацій. Історію законодавства Республіки Таджикистан і практику його застосування в сфері охорони культурної спадщини, а також питання виявлення, вивчення, обліку, охорони, збереження, використання, популяризації пам'яток в радянський і пострадянський періоди вивчали такі дослідники як В. І. Акуленко, М.М. Богуславський, Л. Н. Галенська, Й.Р. Глемза, І. П. Магазінщікова, Н.В. Максаківський, В.Р. Крогіус, А.А. Буторін, В.В. Максимов, І.Е. Мартиненко, О. І. Мельничук, Л. В. Павлова, Н. А. Потапова, Е. В. Утко, О.В. Шуміхіна, С. М. Фазлуллін та інші.

Мета. Здійснити аналіз містобудівного регулювання у сфері охорони культурної спадщини Республіки Таджикистан.

Виклад основного матеріалу. Стратегія збереження культурної спадщини розкриває проблеми охорони, реставрації та використання пам'яток, ансамблів та міського середовища, а також реконструкції, консервації та нового будівництва в історичних районах Республіки Таджикистан. Стратегія політики зазначеної держави підтримує законодавчоправові аспекти збереження і вдосконалення культурної та природної спадщини в сучасному містобудівному середовищі, їх розвиток і захист в цілому.

Пам’ятки культурної спадщини, які знаходяться під державною охороною, мають захист від руйнування або заподіяння їм шкоди, розкрадання або знищення. Громадянська війна перервала природний (еволюційний) процес просування Таджикистану на шляху до створення суверенної і незалежної держави. Вона викликала серйозні політичні потрясіння, які загрожували цілісності та національній безпеці країни, культурному надбанню і творам мистецтв.

Загроза та ослаблення державності Республіки Таджикистан стали причиною духовного і матеріального зубожіння народу, взагалі ігнорувалися закон та порядок в суспільстві, що згодом також вплинуло на стан ізбереження пам'яток національної культурної спадщини, сучасних споруд та будівельних об'єктів. Наприклад, значні об'єкти архітектури (санаторії, курорти і будинки відпочинку, готелі, адміністративні будівлі, житлові будинки тощо) в містах і районах Республіки Таджикистан були розграбовані, спаплюжені, знищені. Руйнування об'єктів та пам'яток культурної спадщини спричинили антропогено обумовлене забруднення, інші форми негативного впливу людської діяльності, а також стихійні природні лиха.

В період громадянської війни було багато руйнувань в галузі будівництва та архітектури, в тому числі були знищені пам'ятки культурної спадщини в містах Вахдат, Турсунзаде, Пенджикент, а також в Рудакі, Гіссарському, Шахрінавському, Айнінському і Кухістоні Мастчохському районах. В період з 1995 по 2010 рр. в Таджикистані було зруйновано понад сто пам'яток $[1,56]$. 
Жителі в результаті незаконного привласнення земель перетворили в руїни стародавні городища, могильники і фортеці. Наприклад, Арк-кала міста Худжанд (Фортеця Темурмаліка), яка сьогодні знаходиться в руйнівному стані через природно-кліматичні фактори, але найбільше цю пам'ятку нівечать люди (несерйозне ставлення відповідальних осіб, привласнення земель і руйнування стіни з боку приватних та юридичних осіб). Одна частина стіни арки входить на територію заводу Торгмаш і в підприємство Ремпобуттехніки, а інша - в ремонтно-будівельне управління та у військову частину № 3501. Необхідно зауважити, що відповідно до статті 24 Закону Республіки Таджикистан «Про охорону і використання об'єктів історико-культурної спадщини» (далі - Закон) використання об'єктів культурної спадщини у військових цілях забороняється [2, 34].

Інший приклад - це руйнування пам'ятки городища Стародавнього Пенджикента через негативний вплив кліматичних природних факторів (означена пам'ятка розташована під відкритим небом), а також з вини вчених-археологів, які недотримуються захисних заходів i методів збереження цієї пам'ятки та залишили розкопки у відкритому просторі.

Крім того, на сьогодні така пам'ятка культурної спадщини як стародавнє поселення Хон-Яйлов - V-VIII ст. в ущелині Ак-Тангі Шахрістанського району міста Істравшан знаходиться в дуже зруйнованому стані, історичне пасовище протоптане ногами людей, які жили в околицях, кладку каменів стіни пам'ятки жителі околиці селища розтягнули для будівництва своїх жител, а біля пам'ятки культурної спадщини Калаі Кахкаха в Шахрістані (м. Істравшан) жителі, безвідповідально і не дотримуючись певних меж площі пам'ятки, побудували власні будівлі.

Також стали стихійно з'являтися дехканські господарства, керівники яких захоплювали землі і використовували їх під посіви, а, наприклад, в Бадахшані стародавні фортеці розтягнули по камінню для будівництва будинків і ферм. Таким чином, дуже важливо, щоб було вирішено питання про передачу земель, на яких розташовані ці пам'ятки культурної спадщини, на баланс відомств культури. Тоді можна буде захистити їх від людського фактору і ці об' єкти набудуть статусу пам'яток [1, 67].

Пам'ятки культурної спадщини національного значення заслуговують на особливу увагу і захист від дедалі більшої загрози їх існуванню внаслідок природних та людських чинників. Необхідно зазначити, що злочинність у сфері національних культурних надбань різних держав сьогодні стала всесвітньо глобальною проблемою, а її причини стали складними і важко переборними.

Таким чином, велика втрата пам'яток культурної спадщини пояснюється: недотриманням законів, неуважність Уряду та його структур, швидке (але неякісне і не на користь культурній спадщині) прийняття Указів Президента Республіки Таджикистан. Договірно-правова база Співдружності Незалежних Держав (СНД) у сфері культури постійно розширюється і вдосконалюється. Держави-учасниці СНД індивідуалізують свої законодавчі і нормативно-правові основи, в результаті чого багато національних галузей у сфері культури відокремлюються, відчужуються в рамках кожної з країн, що тягне за собою проблеми взаємодії та взаєморозуміння. Різко зменшилися можливості для створення загального інформаційного, освітнього, культурного простору в рамках СНД.

Геополітичне становище Республіки Таджикистан ставить проблему його безпеки на чолі всіх інших проблем. Від вирішення геополітичних проблем в регіоні залежить не тільки соціально-економічне зростання, стабільність, життєвий рівень населення, його соціальне благополуччя і реальний суверенітет, а й збереження таджицької культурної спадщини та розвитку культурного туризму в країні. Без культурної спадщини важко уявити сучасне життя Республіки Таджикистан і перспективи ії розвитку.

Культурна спадщина багато в чому формує особливий менталітет таджиків, стверджує спадкоємність гуманістичних цінностей, підкреслює неофіційний статус культурної столиці Республіки Таджикистан. Культурна спадщина включена в різноманітні соціальні процеси і $є$ джерелом духовного збагачення таджицького народу. Структура історичних ансамблів сприяє гармонійній рівновазі в суспільстві, розвитку широкого діапазону діяльності. Мобілізація економічного ресурсу культурної спадщини - основа міської регенерації. Саме високі естетичні якості і ступінь збереження історико-культурного 
середовища можуть забезпечити особливу інвестиційну привабливість Республіки Таджикистан, служити запорукою добробуту їі громадян. Це має виражатися не тільки в негайній економічній віддачі і зростанні зайнятості населення в різних сферах діяльності, але й в широкому колі непрямих вигод, які стануть надбанням всього міського співтовариства (доходи від управління культурною спадщиною, реставрації, туризму та його інфраструктури).

Збереження об'єктів культурної спадщини в містобудівному середовищі Республіки Таджикистан має стати ключовим елементом стратегії міського і сільського оновлення [3, 23]. Принцип комплексного збереження об'єктів архітектури в сучасній міській забудові особливо в умовах глобалізації вимагає потужного використання ініціюючої, контролюючої і координуючої функції органів державного управління в розвитку партнерських відносин 3 громадськістю, недержавним сектором та міжнародною спільнотою.

Завдання збереження культурної спадщини мають вирішуватися не тільки посадовими особами у сфері охорони культурної спадщини, але також і тими структурами, до повноважень яких належать питання містобудування та архітектури, економіки i промислового розвитку, екології, транспорту, благоустрою, майнового комплексу, житловокомунального господарства, юридичних служб тощо.

Виходячи з цього, сьогодні виникає питання про практичне використання пам'яток архітектури (підтримки й відновлення будівель), що представляють історичну, культурну, художню та іншу цінність, i їх безпосередне активне включення до сучасного життя. Саме в історичних зонах формується своєрідне обличчя міста, але постійно розбудовуються сучасні його частини, які не повинні негативно впливати на характер історично сформованої забудови. При використанні пам'яток культурної спадщини поряд з їх історико-художньою цінністю необхідно враховувати й об'ємно-просторову структуру, корисну площу, положення в плані розвитку міста, конфігурацію земельної ділянки, характер нової навколишньої забудови тощо $[4,53]$.

Як показує досвід, збереження традиційних функцій старовинних об'єктів архітектури в їх охоронних зонах найкраще забезпечує збереження пам'яток культурної спадщини та їх середовища, експлуатацію охоронної зони та ії сприйняття в цілому [5, 73]. У більшій частині міста нова забудова з усіх боків обліплює історичне ядро міста і тисне на нього, поступово «перемелюючи» історико-культурні цінності $[6,194]$.

Проблема вивчення збереження пам'яток архітектури в міському середовищі Республіки Таджикистан набуває особливої актуальності в умовах урбанізації, коли відбуваються пошуки з відновлення і збереження історичного образу в сучасних умовах. У зв'язку з цим необхідно розробити наукове обгрунтування застосування реставрації та консервації окремих пам'яток архітектури, ділянок історичної забудови міст, реконструкцію і розвиток інженерної інфраструктури. Ефективному збереженню пам'ятки повинно сприяти іiі правильне використання. Пам'ятку архітектури не треба ізольовувати від сучасного оточення [7, 27].

Наприклад, історична споруда лазні (раніше чайхана старих), яка розташована в центрі міста Худжанд і була побудована в 1958 році, на сьогодні знаходиться в незадовільному стані. Баня була відреставрована двічі за рахунок державних коштів, але сьогодні сама будівля і дах знаходяться в зруйнованому стані в основному через землетрус. Ця пам'ятка культурної спадщини не виконує функцію лазні, як раніше, а приватні особи не мають уявлення правильного використання вказаного об'єкта і проведення ремонтнореставраційних робіт для його збереження. Таких пам'яток в Республіці Таджикистан дуже мало, тому необхідно вибрати правильне рішення для збереження і захисту національної культурної спадщини. Зазначена вище історична споруда має бути включена до Державного реєстру об'єктів історико-культурної спадщини і бути під контролем держави відповідно до статей 13, 14, 16 Закону [2, 20-21].

Необхідно зазначити, що для збереження об'єктів культурної спадщини повинні бути задіяні кваліфіковані фахівці з ремонтно-реставраційних, науково-дослідних, вишукувальних, проектних та виробничих робіт. Термін «реставрація», застосований до міста, видається більш доречним, ніж поширене у країнах Західної Свропи поняття 
«регенерація», хоча в процесі регенерації міст в більшій мірі, ніж при реставрації будівель, застосовуються сучасні матеріали, конструкції, прийоми будівництва, навіть зводяться нові будівлі і споруди, тобто місто в тій чи іншій мірі реконструюється [8].

Сьогодні місту неможливо надати вигляд минулого шляхом відновлення, тому що воно (місто) перетворюється та оновлюється. Це пов'язано із сучасними соціальними вимогами, що цілком можна назвати реконструкцією. Проте, реконструкція повинна бути підпорядкована загальним завданням збереження або відновлення історично сформованої структурної побудови, композиції, національного стилю, архітектурного вигляду.

Різноманітні дані вказують на те, що реставрація і реконструкція менш вигідні для інвестора, ніж нове будівництво, проте в районах з високим показником «центральності» це компенсується вигодами місцеположення, а в менш престижних районах підвищується ризик втрати справжньої історичної забудови. Організаційно-економічні інструменти, дозволяють підвищити інвестиційну привабливість об'єктів культурної спадщини. Виділено три основні групи таких інструментів: субсидування, стимулювання і локалізація особливих правових умов. Головна мета проведеної систематизації - виявлення тих параметрів, які необхідно враховувати в методиках охоронного місторегулювання [6, 34].

Сьогодні розвиток сучасної архітектури в містах Республіки Таджикистан наповнений творчими пошуками, що мають свої позитивні і негативні риси. Необхідно зазначити, що сьогодні в означеній республіці йде бурхливе будівництво. Але, на жаль, при такому сучасному бурхливому будівництві відсутні увага і наукове обгрунтування плану збереження пам'яток архітектури в сучасній міській структурі, фахівці в галузі містобудування, а також кадрова підготовка у вказаній галузі і реставрації. Для підтвердження цього зазначимо, що генеральний план міста Душанбе виконують фахівці Держбуду міста Москви.

У 2010 році Давньо-Согдійське городище Саразм було занесене до Списку всесвітньої спадщини ЮНЕСКО й отримало світове визнання, оскільки відповідає критеріями відбору (II) (III). Статус пам'ятки всесвітньої спадщини присвоюється ЮНЕСКО природному або рукотворного об'єкту для його кращого збереження і популяризації. Цей статус дає додаткові гарантії збереження того чи іншого об’єкта $[9,46]$.

Також до зазначеного Списку планується занести наступні пам'ятки культурної спадщини Таджикистану: буддійський храм Аджіна-Теппа, городище Хульбук, стародавні городища Пенджикента, Тахтім Сангіна, Національний парк Таджикистану, Гіссарську і Ямчунську фортеці, Медресе Ходжа-Машхад і низку інших пам'яток, які є скарбом та надбанням культури таджицького народу.

До нового Реєстру історико-культурних пам'яток Республіки Таджикистан увійшли понад 2000 пам'яток. Проте, це лише попередній список, який буде узгоджуватися i доопрацьовуватися. Важливо не просто зареєструвати всі ці пам'ятки культурної спадщини, а й визначити їх охоронну зону, внести в карти земельного користування районів, зорієнтувати місцеву владу в збереженні цих пам'яток $[1,69]$.

Необхідно зазначити, що відповідно до статті 14 Закону паспортизація кожної пам'ятки обов'язкова $[2,20]$. Сьогодні в регіонах Республіки Таджикистан багато пам'яток архітектури не мають паспорта або повної інформації. Найбільш важливим питанням у справі збереження пам'яток архітектури $є$ правильне виконання відновлювальних робіт та охоронних зон, оскільки багато з них руйнуються і зникають. Їм загрожують серйозні й конкретні небезпеки, такі як природні явища, людський фактор, війни, грабежі, загроза зникнення внаслідок прогресуючого руйнування, руйнування в зв'язку зі зміною призначення або права власності на землю, швидке зростання розвитку міст і туризму, нестача фінансових коштів на ремонтно-реставраційні роботи.

Один з важливих критеріїв - це, звичайно ж, фінансова скрута. За останнє десятиріччя були проведені роботи із збереження пам'яток культурної спадщини. 3 державного бюджету на це було виділено 680 тис. сомоні. Була проведена реконструкція фортець «Хурда» (Ісфара), «Варзі Манор» (Айни), «Хулбук» (Восе), «Шохи Хомуш» (Мумінабад), «Вамар» (Рушан), гробниць «Ахмаді Бузург» (Пенджикент), «Абулкосіма Джелоні» (Істаравшан), «Імам Зайнулобіддін» (Джілікуль) та інших. Проте, на повну реставрацію кожного з них потрібно близько 400-500 тис. сомоні» $[1,72]$. 
Також в збереженні пам'яток культурної спадщини Республіки Таджикистан велику підтримку і допомогу надають міжнародні організації та представництва. Наприклад, Посольством ісламської Республіки Іран в Республіці Таджикистан було надано фінансову допомогу для часткової реставрації мавзолею Саїда Алі Хамадоні в місті Кулябі. 3 боку Уряду Республіки Таджикистан та деяких міжнародних організацій для ремонтних, реставраційних та відновлювальних робіт пам'яток виділені певні кошти тільки деяким 3 них. Багато ж пам'яток культурної спадщини залишаються без уваги. Наприклад, найбільш важливі історико-архітектурні об'єкти в таких історичних містах як Худжанд, Істравшан, Iсфара, Пенджикент, Душанбе, Хісор, Куляб.

Завдяки збереженим пам'яткам, зразкам стародавньої архітектури (ісламським мечетям, буддійським храмам, палацам та суспільно-культурним, житловим будівлям радянських часів) ці міста як і раніше зберігають дух давно минулих часів. Означені вище міста зі своєю великою історією та древніми архітектурними пам'ятками всесвітнього значення $\epsilon$ дуже цікавими для огляду і відвідування туристів, гостей, а також їхнього населення.

На сьогодні в Республіці Таджикистан зареєстровано 1846 пам'ятки культурної спадщини, з них 324 історичні, 1264 стародавніх пам'яток і 258 пам'яток архітектури [1, 78]. На обліку Міністерства культури Республіки Таджикистан знаходиться понад 900 пам'яток археології і 200 пам'яток архітектури. До республіканського списку міст та інших населених історичних точок входять 5 міст Республіки Таджикистан: Душанбе, Істравшан, Худжанд, Пенджикент, Гіссар. До Державного списку всесоюзного значення були занесені 43 пам'ятки культурної спадщини. Серед пам'яток, які перебувають на державному обліку, $\epsilon$ найбільш найдавніші пам'ятки і вони $є$ частиною всесвітньої культурної спадщини.

В Республіці Таджикистан організовано два історико-культурні заповідники: Пенджикент та Гіссарский заповідник. В останньому знаходяться 5 об'єктів архітектурного комплексу середньовічного Гіссара. Археологи щороку ведуть розкопки і відкривають нові культурні шари. Наукові відкриття змушують людину уявити картину того часу. Широкі дослідження поселень «Саразм» (в перекладі «Сарі замін», яке означає «Початок землі»), міста Пенджикент, «Хулбук» Восейського району, «Тахтісангін» Кабадіянського району, безумовно, дадуть нові матеріали для історії, культури та архітектури Республіки Таджикистан.

Для вдосконалення політики держави необхідне активне включення охорони культурної спадщини як складової частини до всіх аспектів міського планування [10, 34]. Відповідно до законодавства Республіки Таджикистан та міжнародних угод держава повинна приймати рішення у сферах міського будівництва, благоустрою та міського господарства, удосконалювати систему управління національної культурної спадщини з урахуванням необхідності їі збереження. Міжнародні організації ЮНЕСКО та ОБСС, Хукумати областей і міста Душанбе безпосередньо розглядають питання збереження та використання пам'яток культурної спадщини, вводять в практику підготовку щорічних доповідей і вносять їх на розгляд Ради із збереження культурної спадщини при Уряді Республіки Таджикистан.

Висновки. Сьогодні в Республіці Таджикистан роль і значимість містобудівної діяльності значно зростає. Це обумовлено підвищенням зростання сучасної будівельної активності, розвитком територій міст та поселень, вдосконаленням інфраструктури, забудовою і реконструкцією столиці й міст, поліпшенням благоустрою та екологічним станом міського середовища, а також досконалістю правового зонування районного планування. Тому правильний підхід, підтримка та подальше забезпечення сталого функціонування міст і поселень Республіки Таджикистан - стратегічна мета державного розвитку.

Таким чином, першочерговим завданням органів державної влади, спеціалізованих установ і громадських організацій сфери культури Республіки Таджикистан $є$ збереження й ефективне використання пам'яток культурної спадщини та залучення їх до сфери соціально-культурної діяльності і туризму. 


\section{Список використаної літератури}

1. За годы независимости в Таджикистане исчезло 100 памятников культуры. 218 с. [Електронний pecypc]. - Режим доступу: http://www.regnum.ru/news/1249406.html

2. Конуни Чумхурии Точикистон «Дар бораи хифз ва истифодаи объектхои мероси таърихию фарханги». 120 с. [Електронний ресурс]. - Режим доступу: http://www.mynet.tj

3. Лавров В. А. Исторические города в их развитии. Сборник материалов. Градостроительные вопросы сохранения и использования памятников архитектуры. - Москва, 1980. - 204 с.

4. Иванов В. Н. Охранные зоны и зоны регулирования в исторических городах. Сборник материалов. Градостроительные вопросы сохранения и использования памятников архитектуры. - Москва, 1980. - 156 с.

5. Тренина А. Б. Сохранение и использование исторической среды памятников архитектуры. Сборник материалов. Градостроительные вопросы сохранения и использования памятников архитектуры. - Москва, 1980. - 234 с.

6. Утко Е. В., Шумихина О. В. Сокровища человечества. Все 962 памятника Всемирного наследия ЮНЕСКО. - Москва: Эксмо, 2013. - 536с.

7. Князев К. Ф. Градостроительные задачи реставрации. Сборник материалов. Градостроительные вопросы сохранения и использования памятников архитектуры. - Москва, 1980. - 176 с.

8. Поточний архів Міністерства культури та інформаційної політики України.

9. Конвенція про охорону всесвітньої культурної і природної спадщини від 16.11.1972. 95 с. [Електронний ресурc]. - Режим доступу: http://www.rada.gov.ua

10. Харковенко Р. В. Науково-методичні аспекти системи обліку пам'яток культурної спадщини // Праці Центру пам'яткознавства. - К.: Центр пам'яткознавства Національної академії наук України і Українського товариства охорони пам'яток історії та культури, 2017. - Вип. 31 C. 29-36.

\section{References}

1. During the years of independence, 100 cultural monuments have disappeared in Tajikistan. $218 \mathrm{~s}$. Retrieved from: http://www.regnum.ru/news/1249406.html. (in Rus.).

2. Law of the Republic of Tajikistan «On protection and use of historical and cultural heritage sites». 120 s. Retrieved from: http://www.mynet.tj. (in Tjk.).

3. Lavrov, V. A. (1980) Historical cities in their development. Collection of materials. Urban planning issues of preservation and use of architectural monuments. Moscow, 204 p. (in Rus.).

4. Ivanov, V. N. (1980) Protection zones and regulatory zones in historic cities. Collection of materials. Urban planning issues of preservation and use of architectural monuments. Moscow, 156 p. (in Rus.).

5. Trenina A. B. (1980) Preservation and use of the historical environment of architectural monuments. Collection of materials. Urban planning issues of preservation and use of architectural monuments. Moscow, 234 p. (in Rus.).

6. Utko E. V., Shumikhina O. V. (2013) Treasures of humanity. All 962 UNESCO World Heritage Sites. Moscow: Exmo, 536 p. (in Rus.).

7. Knyazev, K. F. (1980) Urban planning tasks of restoration. Collection of materials. Urban planning issues of preservation and use of architectural monuments. Moscow, 176 p. (in Rus.).

8. Current archive of the Ministry of Culture and Information Policy of Ukraine. [in Ukr.].

9. Convention for the Protection of the World Cultural and Natural Heritage of 16.11.1972. 95 p. Retrieved from: http://www.rada.gov.ua. (in Ukr.).

10. Kharkovenko R. V. (2017). Scientific and methodological aspects of the system of accounting for cultural heritage monuments // Proceedings of the Center for Monument Studies. Vol. 31. Kyiv: Center for Monument Studies of the National Academy of Sciences of Ukraine and the Ukrainian Society for the Protection of Historical and Cultural Monuments, P. 29-36. [in Ukr.].

KHARKOVENKO Roman, Candidate of Historical Sciences, Chief Specialist of the Ministry of Culture and Information Policy of Ukraine, e-mail: kredo3@ukr.net

\section{THE REGULATION OF URBAN PLANNING IN THE FIELD OF PROTECTION OF CULTURAL HERITAGE OF THE REPUBLIC OF TAJIKISTAN}

Abstract. Introduction. The article considers and analyzes the issue of urban regulation in the field of cultural heritage protection of the Republic of Tajikistan. A review of monument protection legislation 
and principles of public administration, as well as the role of cultural heritage in the life of the people of the republic. The national features of discovery, research, accounting, protection, preservation and use of cultural heritage monuments in the Republic of Tajikistan are highlighted.

Formulation of the problem. Every country in the world strives to protect and preserve its national cultural heritage as effectively as possible. In the legislation of the vast majority of countries of the world, cultural heritage monuments are divided into three categories: local, national and international (global, world) significance (UNESCO monuments). The latter are inscribed on the UNESCO World Heritage List by the relevant decision of the said international organization.

There are as many countries in the world as there are practices for the protection of their own cultural heritage, its preservation, use and promotion. In addition, the aspect of urban planning regulation in the field of cultural heritage protection is extremely important, as cities are constantly being built, changed and developed. Therefore, it is necessary to build a balanced and reasonable state policy on this issue in order to create conditions for the preservation and protection of cultural heritage monuments, as well as to ensure the construction of new buildings. The emphasis should be on the harmonious existence of both monuments and new buildings. In our opinion, the moment of combining the preservation of our own rich cultural heritage with the development of the cities of the Republic of Tajikistan is very interesting.

Objective. To analyze the urban planning regulation in the field of cultural heritage protection of the Republic of Tajikistan.

The research methodology is based on a system of theoretical principles (systematics, historicism, objectivity, etc.), logical methods (analysis and synthesis, induction and deduction, analogy, hypothesis, etc.) and specific research tools that allowed to highlight the aspect of urban planning in the field of cultural heritage protection of the Republic of Tajikistan.

The main results of the research are the study, analysis, generalization and systematization of the basics of national monument protection legislation of the Republic of Tajikistan, as well as consideration of the regulation of its urban planning activities.

The scientific novelty of the study results of the article is to analyze the legislation of the Republic of Tajikistan in the field of cultural heritage protection and compliance of urban planning of the republic with these standards.

Conclusions and specific suggestions of the author. Today in the Republic of Tajikistan the role and importance of urban planning is growing significantly. This is due to increased growth of modern construction activity, development of cities and settlements, improvement of infrastructure, construction and reconstruction of the capital and cities, improvement of urban development and environmental conditions, as well as perfection of legal zoning of district planning. Therefore, the right approach, support and further ensuring the sustainable functioning of cities and settlements of the Republic of Tajikistan is a strategic objective of state development.

Thus, the primary task of public authorities, specialized institutions and public organizations in the field of culture of the Republic of Tajikistan is the preservation and effective use of cultural heritage monuments and their involvement in the field of socio-cultural activities and tourism.

Key words: cultural heritage, cultural heritage protection, cultural heritage object, monument, urban planning activity.

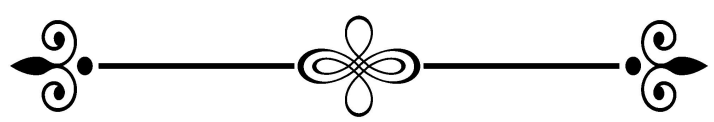

